\title{
МОЖЛИВОСТІ ДЕЛЬФІНОТЕРАПІЇ У РОБОТІ 3 ПІДЛІТКАМИ 3 ПОРУШЕННЯМ ІНТЕЛЕКТУАЛЬНОГО РОЗВИТКУ ЛЕГКОГО СТУПЕНЯ
}

Тетяна Шипелік, Інституту спеціальної педагогіки і психології імені Миколи Ярмаченка НАПН України, tanja575@ukr.net

Констатувальний і формувальний експерименти нашого дослідження проведені на основі розробленої та теоретично обґрунтованої структурної моделі особистості підлітків з інтелектуальними порушеннями, яка охоплює дві ссрери: життєво-смислову і емоційно-вольову. Дібрано й адаптовано психодиагностический комплекс для дослідження особливостей особистісного розвитку підлітків цієї категорії і можливостей їхньої соціально-психологічної адаптації, який передбачає вісім методик.

Особливості особистісного становлення і соціально-психологічної адаптації вивчені на загальній вибірці з 254 підлітків цієї вікової групи. Експериментальну групу становили 150 підлітків 3 інтелектуальними порушеннями легкого ступеня, контрольну - 104 старшокласника з нормальним інтелектом.

Представлено результати експериментального дослідження психологічних особливостей становлення особистості з інтелектуальними порушеннями на підлітковому етапі, і показано позитивний вплив дельфінотерапії на адаптаційні можливості підлітків. Представлена трьохкомпонентна модель корекційно-розвивальної програми, базовим компонентом якої є дельфінотерапія. Корекційно-розвивальна програма об'єднує різні види психологічної корекції для вирішення питань оптимізації особистісного розвитку підлітків даної категорії. Основним компонентом корекційно-розвивальної програми $є$ дельфінотерапія, яка доповнена методами казкотерапії та когнітивної психотерапії. В якості ефективного інструментарію дельфінотерапії в програмі були використані символи дельфінів: їх образи, голоси, казкові і міфічні пеосонажі, іграшки без безпосереднього спілкування підлітків з твариною-терапевтом.

Ключові слова: дельфінотерапія, підлітки з інтелектуальними порушеннями легкого ступеня, дисгармонійний розвиток особистості, корекційно-розвивальна програма, соціально-психологічна адаптація, модель структури особистості, модель корекційно-розвивальної програми з оптимізації особистісного розвитку підлітків.

Татьяна Шипелик, Институт специальной педагогики и психологии имени Николая Ярмаченко НАПН Украины, г. Киев, Украина

Возможности дельфинотерапии в работе с подростками с нарушениями интеллектуального развития легкой степени

(C) Шипелік Т., 2019

«ОСОБЛИВА ДИТИНА: навчання і виховання», № 3, 2019 
Дельфинотерапия обладает мощным терапевтическим, гармонизирующим и развивающим потенциалом, создает психологическое благополучие у человека, но недостаточно широко используется в коррекционных программах из-за ее малочисленных исследований. Констатирующий и формирующий експерименты нашего исследования проведены на основе разработанной и теоретически обоснованной структурной модели личности подростков с интеллектуальными нарушениями, которая включает в себя две сферы: жизненно-смысловую и эмоционально-волевую. Подобран и адаптирован психодиагностический комплекс для исследования особенностей личностного развития подростков данной категории и возможностей их социально-психологической адаптации, который включает в себя восемь методик. Особенности личностного становления и социально-психологической адаптации изучены на общей выборке из 254 подростков данной возрастной группы. Экспериментальную группу составили 150 подростков с интелектуальными нарушениями легкой степени, контрольную - 104 старшеклассника с нормальным интеллектом.

В статье представлены результаты експериментального исследования психологических особенностей становления личности с интеллектуальными нарушениями на подростковом этапе, и показано позитивное влияние дельфинотерапии на адаптационные возможности подростков. Представлена трехкомпонентная модель коррекционно-развивающей программы, базовым компонентом которой является дельфинотерапия. Коррекционноразвивающая программа объединяет различные виды психологической коррекции для решения вопросов оптимизации личностного развития подростков данной категории. Основным компонентом коррекционно-развивающей программы является дельфинотерапия, которая дополнена методами сказкотерапии и когнитивной психотерапии. В качестве эфффективного инструментария дельфинотерапии в программе были использованы символы дельфинов: их образы, голоса, сказочные и мифические герои, игрушки без непосредственного общения подростков с животным-терапевтом.

Ключевые слова: дельфинотерапия, подростки с интеллектуальными нарушениями легкой степени, дисгармоничное развитие личности, коррекционно-развивающая программа, социально-психологическая адаптация, модель структуры личности, модель коррекционно-развивающей программы по оптимизации личностного развития подростков.

Tetjana Shipelik, Mykola Yarmachenko Institute of Special Education and Psychology of the NAES of Ukraine (Ukraine) tanja575@ukr.net

Opportunities of dolphin therapy in work with adolescents with mild intellectual disorders

The ascertaining and forming experiments of our research were carried out based on the developed and theoretically substantiated structural model of the personality of adolescents with intellectual disabilities, which includes two areas: life-meaning and emotional-willed. A psychodiagnostic complex was selected and adapted to study the characteristics of the personal development of adolescents in this category and the possibilities of their socio-psychological adaptation, which includes eight methods.

Features of personal development and socio-psychological adaptation were studied based on a total sample of 254 adolescents. The experimental group consisted of 150 adolescents with mild intellectual disorders, while the control group consisted of 104 senior students of secondary schools in the city of Kiev. 
The article presents the results of an experimental study of the psychological characteristics of the formation of a person with intellectual disabilities at the adolescent stage, and shows the positive impact of dolphin therapy on the adaptive capabilities of adolescents. A threecomponent model of a correctional development program based on dolphin therapy is presented here. The correctional development program combines various types of psychological correction to address issues of optimizing the personal development of adolescents in this category. The main component of the correctional-development program is dolphin therapy, which is supplemented by methods of fairy-tale therapy and cognitive psychotherapy. The dolphin symbols were used as effective tools for dolphin therapy: their images, voices, fairytale and mythical heroes, toys without the direct communication of adolescents with the animal therapist.

Keywords: dolphin therapy, adolescents with mild intellectual disabilities, disharmonious personality development, correctional and developmental program, socio-psychological adaptation, personality structure model, model of the correctional developing program for optimization of personal development of teenagers.

Постановка проблеми. Усе частіше психологи, соціальні працівники, лікарі, корекційні педагоги, батьки обирають анімалотерапію для відновлення порушеного соціального розвитку дітей з особливими потребами завдяки унікальним можливостям тварин відчувати і використовувати приховані резерви людини. Незважаючи на великі потенційні можливості цього методу, багато експертів вважають, що нечисленні дослідження анімалотерапії не дозволяють застосовувати їі широко в психокорекційній роботі у дітей з особливими потребами. Проте, інструментарій анімалотерапії, окрім безпосереднього спілкування дитини з твариною-терапевтом, включає символи тварин: їх образи, голоси, казкових персонажів, іграшки, які сприяють створенню психологічного благополуччя у пацієнта і не знижують ефективності цього методу навіть без участі тварини. Дельфінотерапія, як вид анімалотерапії, може більш широко та успішно впроваджуватися в корекційно-розвивальні програми у дітей, якщо в якості тварин-терапевтів у ній будуть використані символи дельфінів. Ця ідея була покладена в розробку формувального експерименту нашого дослідження з оптимізації особистісного розвитку підлітків з інтелектуальними порушеннями легкого ступеня.

Аналіз актуальних досліджень. Дослідження в області дельфінотерапії мають міждисциплінарний характер і їі розвиток тісно пов'язаний з етологією, зоопсихологією, психотерапією, курортологією, біофізикою, спеціальною психологією, корекційною педагогікою та іншими науками.

Живі організми, як відкриті системи не можуть існувати без обміну між собою і навколишнім простором, речовиною, енергією й інформацією, тому наукове обгрунтування методу дельфінотерапії тісно пов'язане з питанням існування біополів живих організмів.

Новітні наукові дані переконливо свідчать, що життя існує у вигляді польових структур, у яких біологічні об'єкти - це складні приймальні системи, резонансні контури, у яких нервова система виконує комунікативну роль. На думку сучас-

«ОСОБЛИВА ДИТИНА: навчання і виховання», № 3, 2019 
них дослідників, фізичне і психічне здоров'я може забезпечити тільки повноцінне функціонування механізмів інформаційного гомеостазу, тому стан здоров'я людини безпосередньо залежить від якості біополя, за допомогою якого ми інтегровані у світову Єдність. Людина - це частинка Космосу, і їі комунікативні здібності до спілкування з усім, що живе на Землі, зокрема з нашими братами меншими, визначають або гармонійність або дисгармонійність його психоемоційної сфери.

За даними Ю. Гуляєва і Е. Годика у людини виділяють шість основних біополів: інфрачервоне, радіотеплове, акустотеплове, оптична хемолюмінісценція, електричне поле, магнітне поле. Біологічні поля, що породжуються різноманітними випромінюваннями, виникають у процесах обміну речовин в організмах людини і тварин; і забезпечують взаємозв'язок живих організмів один з одним (Ю. Гуляєв, Е. Годик, 1983).

Дослідники біополя виділяють чотири універсальні закони енергетичної активності, які описують взаємодію організмів і навколишнього світу, і поширюються на анімалотерапію:

1) готовність організму, як об'єкта, до дії - реакції, а також самі дії - усе починає формуватися заздалегідь на енергетичному рівні, як модель поведінки i згодом може повернутися до початкового стану або ж проявитися в певних функціональних або морфологічних зрушеннях;

2) усяка дія або взаємодія організму із зовнішнім середовищем і вплив на нього знаходять відображення в зміні його біоенергетичної активності;

3) спеціальною дією (наприклад, моделюванням діï) можна змінювати біоенергетичну активність організму, органу, тканини; велике значення тут належить психічній саморегуляції і їі психоенергетичному прояву;

4) у процесі існування організму або об'єкта формується його своєрідний біоенергетичний (енергетичний) образ. Надалі цей образ зберігається незалежно від об'єкта, а також після припинення його діяльності або існування, має певну автономність і не залежить від просторових і тимчасових взаємовідношень самого об'єкта (Концепция способа гармонизации психоэмоционального состояния человека, 2000).

Зарубіжний і вітчизняний досвід використання дельфінотерапії у дітей 3 особливими потребами узгоджується з цими даними. Д. Натансон відмітив, що в процесі взаємодії з дельфінами дітей, які мають інтелектуальні порушення, активізується психомоторний і мовний розвиток (Nathanson D, 2001). Поліпшення психоемоційного стану та поліпшення соціальної адаптації пацієнтів з широким спектром психоневрологічної патології після розробленої системи реабілітації з участю дельфінів на вибірці більш ніж 2000 респондентів встановлене Л. Лукіною (Л. Лукіна, 2007).

На Україні потужний реабілітаційний потенціал дельфінотерапії у дітей 3 психоневрологічною патологією доведений та обгунтований у роботах А. Чуприкова. Учений сприяє розвитку цього методу на Україні і вважає, що дельфінотерапія може застосовуватися не тільки з лікувальною метою, а також має соціально-психологічне і психокорекційне значення (А. Чуприков, 2013, 2016). 
Для розробки моделі формуючого експерименту велике значення також мали дані, які отримані Л Тхомаковою. Дослідниця довела, що для підвищення адаптаційного потенціалу можливе використання такого елементу дельфінотерапії, як біоакустичні сигнали дельфінів без безпосереднього контакту із самою твариною (Л. Тхомакова, 2015).

Метою статті є висвітлення результатів формувального експерименту, який був проведений за допомогою корекційно-розвивальної програми на основі дельфінотерапії з оптимізації особистісного розвитку підлітків з інтелектуальними порушеннями легкого ступеня.

Методи дослідження. Концентуальною основою дослідження особистісного становлення в умовах недостатності інтелектуального розвитку на підлітковому етапі найбільш прийнятним є суб'єктно-буттєвий підхід, на основі якого можливо визначити розвивальні, коректувальні профілактичні й реабілітаційні завдання для педагогічної практики. Особистість підлітка одночасно є і суб'єктом розвитку, і суб'єктом діяльності, і суб'єктом життя. Людина як суб'єкт є системною цілісністю психічних процесів, станів і властивостей, тобто в суб'єкті оптимально представлені потребово-мотиваційний, психофізіологічний, когнітивний і ціннісно-смисловий аспекти психіки. Виходячи з представлених теоретичних положень констатувальний експеримент був проведений на основі теоретично обгрунтованої і розробленої структурної моделі особистості підлітків з інтелектуальними порушеннями, яка охоплює в себе дві сфери: життєво-смислову і емоційно-вольову. Життєво-смислова сфера відповідальна за надбання сенсу життя, а також прагнення реалізувати себе, прагнення до автентичного буття. Емоційно-вольова сфера відповідальна за духовний вимір особистості, а також за узгодженість і цілісність внутрішнього світу особистості.

Виклад основного матеріалу. Модель формувального експерименту у вигляді корекційно-розвивальної програми містить наступні складові: дельфінотерапія, казкотерапія, когнітивна психотерапія. Базовою складовою моделі - є дельфінотерапія, яка оптимізує особистісний розвиток і соціально-психологічну адаптацію підлітків з інтелектуальними порушеннями.

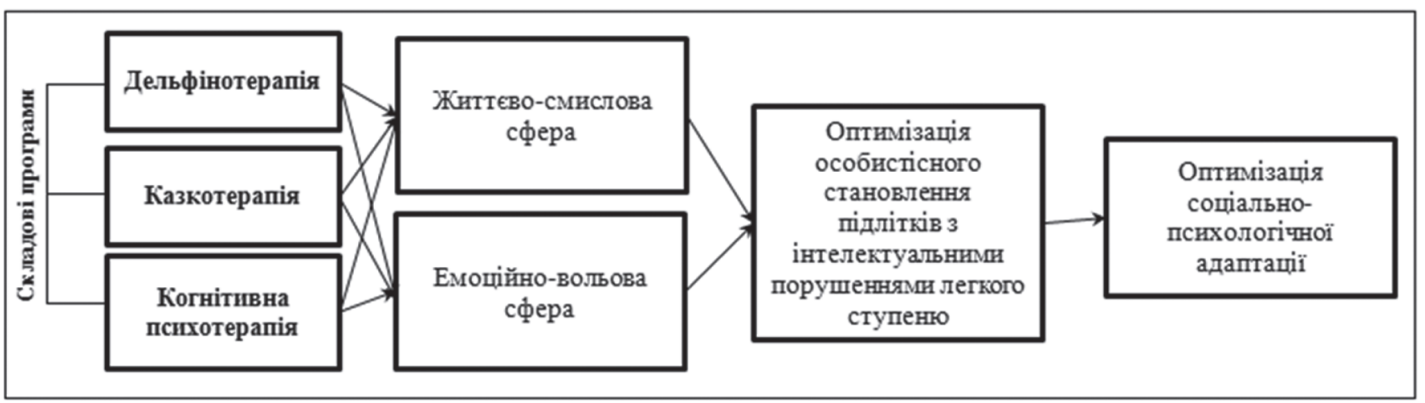

Мал 1. Модель корекційно-розвивальної програми з оптимізації особистісного розвитку підлітків 


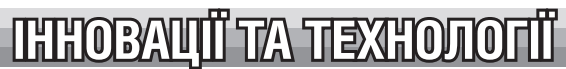

Завданнями розробленої корекційно-розвивальної програми стали: гармонізація у підлітків з легкою інтелектуальною недостатностю системи уявлень про особливості особистісного саморозвитку; сприяння усвідомленню ними власних особистісних характеристик; розвиток емоційного інтелекту, розширення ціннісних орієнтацій, корекція самооцінки, гармонізація іх Я-концепції.

Констатуючий експеримент дослідження переконливо показав, що особистісний розвиток підлітків з інтелектуальними порушеннями має дисгармонійний характер.

Емпіричне дослідження охоплювало експериментальну групу: 150 підлітків з інтелектуальними порушеннями легкого ступеня у віці 14-15 років і контрольну: 104 старшокласника без порушень інтелекту. Загальна кількість вибірки становила 254 підлітки.

Гармонійність особистісного розвитку визначається рівнем сформованості життєво-смислової і емоційно-вольової сфер, які досліджували за допомогою наступних методик: адаптованого автором тесту смисложиттєвих орієнтацій Д. Леонтьєва, методики «Життєве призначення» О. Моткова, методики «Тип мислення» Г. Резапкіної, методики «Готовність до саморозвитку» В. Павлова, тесту на інтегральний емоційний інтелект Н. Холла. Особливості соціальнопсихологічної адаптації підлітків з інтелектуальними порушеннями вивчали за допомогою тесту соціально-психологічної адаптації в модифікації О. Осницького і тесту «Життєстійкості С. Мадді.

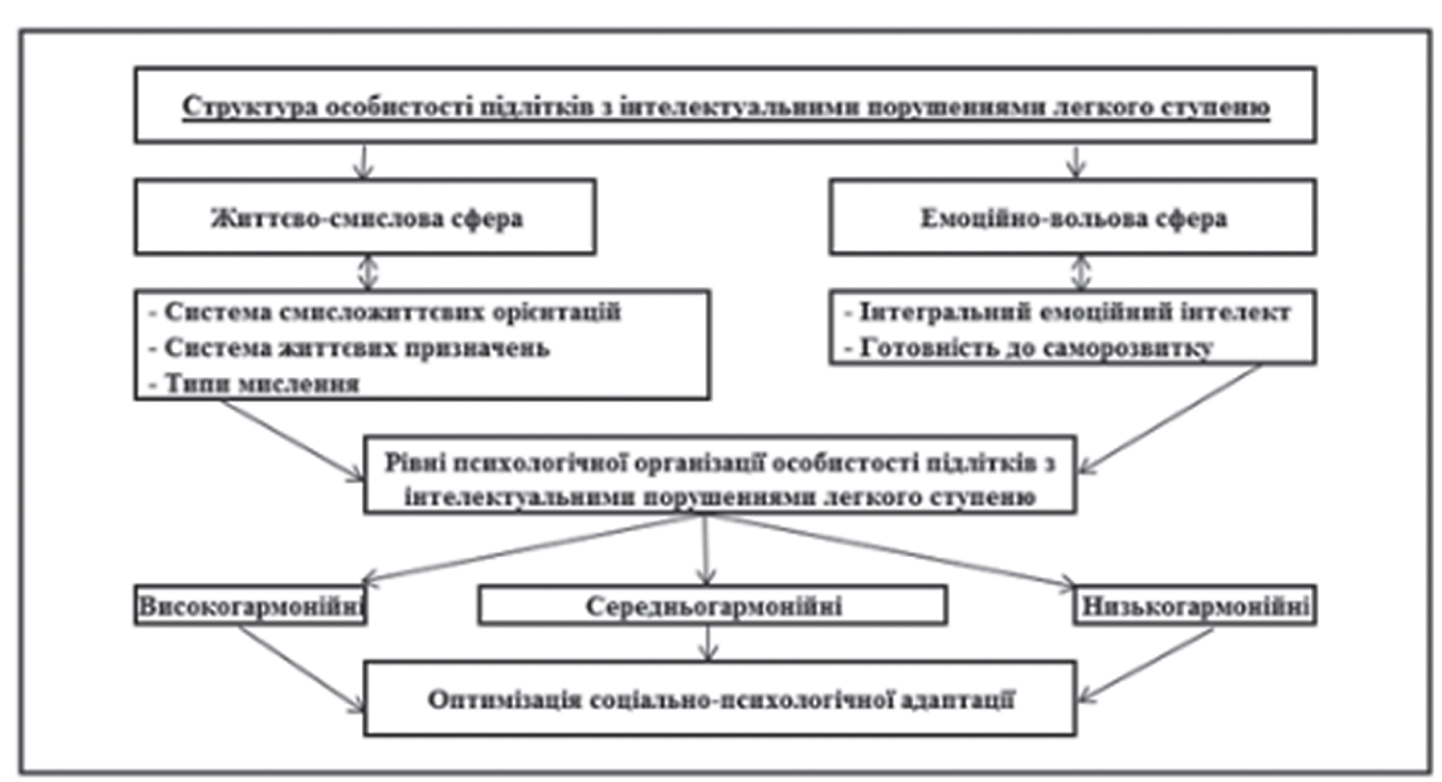

Мал. 2. Структурна теоретико-експериментальна модель особистості підлітків з інтелектуальними порушеннями 
За допомогою цієї моделі створений діагностичний комплекс для дослідження особливостей особистісного розвитку підлітків.

Провідною методикою констатуючого експерименту обрана методика О. Моткова «Базові прагнення», яка дала змогу визначити рівні особистісного розвитку в підлітків з інтелектуальними порушеннями легкого ступеня: «високогармонійні», «середньогармонійні» та «низькогармонійні». Більшість підлітків експериментальної групи (82,7\%) показали «низькогармонійний» рівень, 3-поміж них немає «високогармонійних» підлітків. Чим вище рівень гармонійності особистості, тим оптимальніше рівень розвитку життєво-смислової та емоційно-вольової сфер особистості підлітків.

За результатами констатувального експерименту визначено психологічні особливості життєво-смислової сфери підлітків із порушеннями інтелекту, для якої характерна низька осмисленість життя, а також низький рівень усвідомлення смисложиттєвих орієнтацій: низька цілеспрямованість, низька задоволеність прожитим відрізком життя, відсутні смислові мотиви на побудову свого майбутнього, відсутнє відчуття підконтрольності подій, що загалом ускладнює процес особистісного розвитку. За даними констатувального експерименту життєво-смислова сфера підлітків з інтелектуальними порушеннями також характеризується низькою вираженістю творчої і духовної життєвих орієнтацій; низьким рівнем здійснення життєвих призначень, котрі зумовлені наступними психологічними особливостями особистості підлітків з інтелектуальними порушеннями легкого ступеня: переважанням зовнішнього локусу контролю над внутрішнім, низькою усвідомленістю життєвих призначень, слабкою вірою в здійснення життєвих призначень, слабкою їх усвідомленістю, ригідністю. За даними констатувального експерименту для життєво-смислової сфери підлітків з інтелектуальними порушеннями характерні низький рівень розвитку абстрактно-символічного і творчого мислення, що суттєво затримує процес особистісного становлення.

За результатами констатувального експерименту визначено, що емоційновольова сфера підлітків з інтелектуальними порушеннями характеризується низьким рівнем розвитку емоційного інтелекту: низька самомотивація, низька емоційна обізнаність, низький рівень емпатії більш ніж у половини підлітків, низька здатність управління своїми емоційними станами.

Низький рівень функціонування життєво-смислової та емоційно-вольової сфер обумовлюють особливості соціально-психологічної адаптації підлітків 3 інтелектуальними порушеннями. За даними констатувального експерименту встановлено, що для 40 \% підлітків експериментальної групи властивий низький рівень адаптації до соціального середовища. Цьому сприяють такі констатовані психологічні особливості особистості: низький рівень самоприйняття більш ніж у половини підлітків, екстернальний локус контролю, низька емоційна комфортність.

Корекційно-розвивальна програма 3 оптимізації особистісного розвитку підлітків з інтелектуальними порушеннями передбачала алгоритм формування життєво-смислової і емоційно-вольової сфер підлітків. Кожна складова програми має свою мету, зміст, специфічні прийоми і методи роботи.

«ОСОБЛИВА ДИТИНА: навчання і виховання», № 3, 2019 
Складова дельфінотерапії була спрямована на становлення емоційного інтелекту, активізацію наочно-дієвого мислення, розвитку словесно-логічного, творчого і наочно-образного видів мислення, становленню комунікативних можливостей, що сприяло узгодженому функціонуванню життєво-смислової і емоційно-вольової сфер та їх розвитку.

Казкотерапія була спрямована на розвиток пізнавальних процесів, розвиток творчості, оптимізації емоційно-вольової сфери з метою усвідомлення власних можливостей та розв'язання конкретних завдань міжособистісної взаємодії з однолітками та дорослими в майбутньому. Проблема становлення особистості в умовах порушення інтелектуального розвитку тісно пов'язана з проблемою засвоєння суспільно-культурного досвіду. У підлітків з інтелектуальними порушеннями легкого ступеня із-за слабкості абстрактно-логічного мислення образні форми пізнання дійсності продовжують домінувати, тому наступною важливою складовою програми обрано казкотерапію.

Методи дельфінотерапії і казкотерапії мають багато спільного: обидва методи мають декілька рівнів дії на особистість (рівень свідомості, підсвідомий рівень, глибинний рівень), викликають у дітей емоційний резонанс, активізують конкретно-образне мислення, акумулюють досягнення багатьох наук, передача культурного досвіду за допомогою цих методів межує з мистецтвом. Багато сюжетів казок, притч, байок звертаються до образів тварин, а знайомство з дельфінами на корекційних заняттях відносить в атмосферу казок.

У розробленій корекційно-розвивальній програмі використовують різні методи роботи 3 казкою: аналіз казки під час групового обговорення, рішення завдань за мотивами казок, метод розповіді казок у поєднанні з психорелаксуючими вправами, метод складання казок. Застосування різних методів роботи з казкою в поєднанні з дельфінотерапією дає можливість максимально розвивати творче початок в особистості, звертатися до власного життєвого досвіду, збагачувати своє сприймання, здобувати нові знання, розвивати вміння відчути зародження нового.

Першою умовою виникнення творчих ідей є чутливість - здатність сприймати інформацію, що надходить через органи чуття. Тому початковим етапом корекційно-розвивальної програми є тренування за допомогою спеціальних вправ та розвиток пізнавальних психічних процесів: відчуття, сприймання, уваги, розвиток навичок та умінь помічати відмінності та визначати унікальність об'єктів.

Когнітивна психотерапія була спрямована на оптимізацію мислення, розвиток самомотивації та цілеспрямованості, уміння ставити перед собою завдання. Когнітивна психотерапія сприяє в основному розвитку життєво-смислової сфери. У контексті цієї програми було використано кілька методів та прийомів активізації і гармонізації особистісного розвитку, а саме: творчі завдання, ігри, вправи, моделювання комунікативних ситуацій тощо.

Усі складові корекційно-розвивальної програми сприяють створенню позитивного емоційного фону, від якого значною мірою залежить «емоційне здоров’я» особистості. Спираючись на дослідження сучасних учених, К. Кунерт вважає, що позитивні емоції від спілкування з дельфінами здатні миттєво інтегрувати всі функції й адаптувати організм людини до змін у середовищі (Кунерт, 2013). 
Експериментальна апробація розробленої корекційно-розвивальної програми 3 оптимізації особистісного розвитку підлітків з інтелектуальними порушеннями передбачала перевірку їі ефективності шляхом порівняльного зіставлення результатів.

Порівняння даних до і після формувального експерименту за методикою О. Моткова «Базові прагнення», яка визначає рівні гармонійності, отримано такі дані.

\section{Таблиия 1}

\section{Розподіл респондентів за рівнем показнику «гармонійність} ядра особистості» до і після формувального експерименту

\begin{tabular}{|c|c|c|c|c|}
\hline \multirow{2}{*}{ Групи досліджуваних } & \multicolumn{4}{|c|}{ Гармонійність ядра особистості } \\
\cline { 2 - 5 } & \multicolumn{4}{|c|}{ Високогармонійні підлітки } \\
\cline { 2 - 5 } & До експерименту & \multicolumn{2}{|c|}{ Після експерименту } \\
\cline { 2 - 5 } & Абс. ч. & $\%$ & Абс. ч. & $\%$ \\
\hline Експериментальна гр. (n=150) & - & - & 2 & 1,3 \\
\hline \multicolumn{5}{|c|}{ Середньогармонійні підлітки } \\
\hline Групи досліджуваних & До експерименту & Після експерименту \\
\cline { 2 - 5 } & Абс. ч. & $\%$ & Абс. ч. & $\%$ \\
\hline Експериментальна гр. (n=150) & 26 & 17,3 & 74 & 49,3 \\
\hline \multicolumn{5}{|c|}{ Низькогармонійні підлітки } \\
\hline Групи досліджуваних & До експерименту & Після експерименту \\
\cline { 2 - 5 } & Абс. ч. & $\%$ & Абс. ч. & $\%$ \\
\hline Експериментальна гр. (n=150) & 124 & 82,7 & 74 & 49,3 \\
\hline
\end{tabular}

У результаті проведеної роботи значно зменшилася кількість низькогармонійних підлітків з 82,7 \% до 49,3 \% в експериментальній групі $(\mathrm{p}<0,01)$ і збільшилася кількість середньогармонійних підлітків з 17,3 \% до 49,3 \% $(\mathrm{p}<0,01)$.

Узагальнений аналіз розвитку життєво-смислової сфери у підлітків з інтелектуальними порушеннями за адаптованим автором тестом «смисложиттевих орієнтацій» Д. Леонтьєва до початку формувального експерименту та в кінці свідчить про те, що більшість дітей зазначеної категорії показала позитивну динаміку розвитку: так, зменшилася кількість підлітків експериментальної групи 3 низьким рівнем осмисленості життя з 98,6 \% до 42 \% (p<0,01), тоді, як кількість підлітків з середнім показником осмисленості життя збільшилась з 1,3\% до $57,3 \%(\mathrm{p}<0,01)$.

Узагальнений аналіз розвитку емоційно-вольової сфери за методикою В. Павлова «готовність до саморозвитку» у підлітків експериментальної групи до початку формувального експерименту та після нього свідчить про те, що зменшилась кількість підлітків з низьким рівнем готовності до саморозвитку з 35,3 \% до 19,3 \% ( $<0,01)$, тоді як кількість підлітків з достатнім рівнем готовності до саморозвитку збільшилась з-поміж цієї категорії з 0 \% до 41,3%.

Висновки та перспективи подальших наукових розвідок. Узагальнений аналіз експериментальних даних у підлітків з порушеннями інтелекту до експерименту 
та після його закінчення свідчить про те, що більшість дітей зазначеної категоpiї показала позитивну динаміку особистісного розвитку: так зменшилася кількість низькогармонійних підлітків з 82 \% до $49 \%$; $(\mathrm{p}<0,01)$, тоді як кількість середньогармонійних підлітків збільшилася з 17 \% до 49 \%; $(\mathrm{p}<0,01)$. Після формувального впливу в експериментальній групі з'явилася незначна представленість досліджуваних підлітків експериментальної групи серед високогармонійних підлітків (1,3\%).

Результати формувального експерименту продемонстрували наявність якісних змін особистісного розвитку підлітків, поліпшенню психологічних якостей особистості після проведення корекційно-розвивальної роботи з опорою на дельфінотерапію.

Отже, результати формувального експерименту переконливо доводять, що більшість підлітків з інтелектуальними порушеннями легкого ступеню здатна до усвідомленого особистісного розвитку. Дельфінотерапія як базова складова корекційно-розвивальній програми сприяє гармонізації особистісного становлення та поліпшує соціально-психологічну адаптацію підлітків.

Перспектива подальших розвідок полягає в обгрунтуванні генедерних відмінностей особистісного становлення підлітків 3 інтелектуальними порушеннями легкого ступеня.

\section{ЛITEPATYPA}

1. Гуляев Ю. В., Годик Э. Э. Физические поля биологических объектов. - Вестник АН CCCP. - 1983. - №8. - c. 118-125.

2. Ермолаев О. Ю. Математическая статистика для психологов: Учеб. для вузов; Рос. акад. обр-ния. Моск. психол.-соц. ин-т. - М.: Флинта, 2003. - 170 с.

3. Концепция способа гармонизации психоэмоционального состояния человека. Серия «Технология». Академия развития способностей «Гармония». http://www.osoznanie.biz/info/ concept_gar.pdf.

4. Лукина Л. Н. Дельфины в системе психофизической реабилитации людей / Л. Н. Лукина - Севастополь, 2007. - 170 c.

5. Мотков О. И. Методика «Базовые стремления личности» // Школьный психолог. 1998. № 35. C. $8-9$.

6. Тхомакова Л. Ж. Действие «голоса» дельфина на адаптационные резервы человека: дисс. ... канд. биол. Наук: 03.03.01/ Тхомакова Лиана Жраслановна. - Нальчик, 2015. - 168 с.

7. Украинские дельфинарии и их социально-психологическая функция / А. П. Чуприков, В. Д. Мишиев, Н. М. Марканов [и др.]. // Чоловіче здоров'я, гендерна та психосоматична медицина. - 2016. - № 2(04). - С. 65-69.

8. Чуприков А. П. Современное состояние дельфинотерапии/А. П. Чуприков, С. В. Келюшок, Б. П. Поповский // Здоров'я суспільства. -Киів, 2013. Т. 2, № 1.- С.75-81.

9. Kuhnert K. Delphintherapie - Beweis eines Wunders. Uber die Heilkraft der Delphine. Munchen, 2004.

10. Nathanson D. Dolphin Human therapy: A Professional Association Dedicated to Helping Disabled Children / Nathanson D. // J. Acoust Soc. Amer. - 2001. - Vol. 5. - P. 1123 - 1127. 


\section{REFERENCES (TRANSLATED AND TRANSLITERATED)}

1. Guljaev Ju.V., GodikJe.Je. (1983). Fizicheskie polja biologicheskih ob\#ektov [Physical fields of biological objects]. - Vestnik AN SSSR. - Academy of Sciences of the USSR bulletin, 8, 118125 [in Russian].

2. Ermolaev O.Ju. (2003). Matematicheskaja statistika dlja psihologov [Mathematical statistics for psychologists]. Moskva:Flinta [in Russian].

3. Koncepcija sposoba garmonizacii psihojemocional'nogo sostojanija cheloveka (2000). [Concept of a way of harmonization of a psychoemotional condition of the person]. Serija «Tehnologija». Akademija razvitija sposobnostej «Garmonija». Retrieved from: http://www. osoznanie.biz/info/concept_gar.pdf

4. Lukina L. N. (2007). Del'finy v sisteme psihofizicheskoj reabilitacii ljudej [Dolphins in the system of psychophysical rehabilitation of people]. Sevastopol'[in Russian].

5. Motkov O. I. (1998). Metodika «Bazovye stremlenija lichnosti» [Technique «Basic of the personality»]. Shkol'nyj psiholog.-School psychologist, 35, 8 -9 [in Russian].

6. Thomakova L. Zh. (2015). Dejstvie «golosa» del'fina na adaptacionnye rezervy cheloveka [The action of the "voice" of a dolphin on the adaptation reserves of the human voice] (Doctoral dissertation, Nalchik).

7. Ukrainskie del'finarii i ih social'no-psihologicheskaja funkcija / A.P. Chuprikov, V.D. Mishiev, N.M. Markanov [i dr.]. (2016). [Ukrainian dolphinariums and their social and psychological function]. Muzhskoe zdorov'e:gendernaja i psihosomaticheskaja medicina - Male health: gender and psychosomatic medicine, 2, 65-69 [in Russian].

8. Chuprikov A. P. (2013). Sovremennoe sostojanie del'finoterapii [Current state of dolphin therapy]. Zdorov'e obshhestva - Health of society, Volume 2, No. 1, 75-81.

9. Kuhnert K. (2004). Delphintherapie - Beweis eines Wunders. Uber die Heilkraft der Delphine.

10. Nathanson D. (2001). Dolphin Human therapy: A Professional Association Dedicated to Helping Disabled Children / Nathanson D. // J. Acoust Soc. Amer.

«ОСОБЛИВА ДИТИНА: навчання і виховання», № 3, 2019 